\title{
KAJIAN KERUSAKAN BANGUNAN SEDERHANA PASCA GEMPA BANJARNEGARA 18 APRIL 2018
}

\author{
Elvis Saputra $^{1)}$, Restu Faizah ${ }^{2)}$ \\ ${ }^{1)}$ Mahasiswa Magister Rekayasa Kegempaan, Fakultas Teknik \\ Sipil dan Perencanaan, Universitas Islam Indonesia \\ Jl. Kaliurang Km. 14,5 Yogyakarta, 55584 \\ Email: elvizsaputra95@gmail.com \\ ${ }^{2)}$ Staf Pengajar Program Studi Teknik Sipil, Fakultas Teknik, \\ Universitas Muhammadiyah Yogyakarta \\ Jl. Lingkar Selatan Tamantirto, Kasihan, 55183
}

\begin{abstract}
The 4.4 SR earthquake occurred in Banjarnegara Regency, especially Kalibening subdistrict, on Wednesday, April 18, 2018. Although it has not high magnitude, the structural damage was severe. There were 201 units of structural damage in term of medium to large. It generates the question from stakeholders, what cause of the structural damage. Therefore, this study visited the affected areas of Banjarnegara Earthquake to investigate the causative factor of structural damage, especially for a simple structure which is residential houses, schools and mosque buildings. The study found some causative factors of structural damages. The first is the depth of the earthquake source that is quite shallow i.e. $4 \mathrm{~km}$. The second is the quality of simple buildings that were damaged or collapsed in the affected area might do not have a good quality and do not qualify for earthquake resistant buildings. The sample of cases found in the field is the structural systems that have not good integrated and good material. Besides that, It was found a community innovation to reduce building costs but they did not have the correct method. An example is the use of bamboo as a substitute for steel reinforcements in the frame. Based on this study, the further research into the bamboo usage guidelines as a substitute for steel reinforcement should be carried out and socialized.

Keywords: Earthquake, structural demage, causative factor.
\end{abstract}

\begin{abstract}
Abstrak
Rabu 18 April 2018 Kabupaten Banjarnagara tepatnya di Kecamatan Kalibening dilanda gempabumi dengan kekuatan 4,4 SR, meskipun magnitud gempa tidak terlalu besar namun kerusakan bangunan yang di timbulkan cukup banyak, tercatat dampak yang ditimbulkan oleh gempa sebanyak 201 bangunan mengalami kerusakan mulai dari rusak sedang hingga rusak berat. Fakotr penyebab banyaknya bangunan yang mengalami kerusakan adalah karena memiliki kedalaman pusat gempa yang cukup dangkal, yaitu $4 \mathrm{Km}$ menyebabkan intensitas guncangan di purmakaan tanah terasa cukup kuat. Selain dari faktor kedalaman pusat gempa, banyaknya bangunan rumah, sekolah dan masjid yang rusak atau roboh disebabkan karena tidak mengikuti kaidah-kaidah bangunan tahan gempa. Contoh kasus yang ditemukan di lapangan seperti sistem struktur yang kurang menyatu dan kualitas material yang kurang baik. Dilokasi kerusakan ditemukannya inovasi-inovasi masyarakat dalam menekan biaya bangunan seperti pengunaan bambu sebagai pengganti tulangan baja dan ada juga yang mengkombinasikan dalam satu frame struktur menggunakan tulangan bambu dan tulangan baja, namun penerapan bambu sebagai pengganti tulangan oleh masyarakat tidak dibuat dengan praktek yang semestinya.

Kata Kunci: Gempa, Kerusakan bangunan, Faktor penyebab.
\end{abstract}

\section{PENDAHULUAN}

Kabupaten Banjarnegara merupakan kabupaten yang berada di Provinsi Jawa Tengah, yang memiliki banyak potensi terjadinya bencana. Ancaman yang paling sering terjadi adalah longsor dan gempa bumi. Belum lama ini telah terjadi gempa bumi pada Rabu, 18 April 2018 di Kecamatan Kalibening, yang melanda 4 desa yaitu Desa Plorengan, Kasinoman, Kertosari dan Desa Sidakangen. Kejadian ini menyebabkan timbulnya beberapa korban jiwa dan kerusakan bangunan yang cukup banyak. Tercatat dari BNPB dampak yang diakibatkan oleh gempa Banjarnegara sebanyak 2 orang meninggal, sekitar 35 lainnya luka-luka, dan sebanyak 201 rumah mengalami kerusakan dari tingkat sedang hingga berat.

Jika dilihat dari kekuatan gempa, magnitude yang terjadi tidak terlalu besar, namun dampak kerusakan bangunan yang ditimbulkan cukup parah, terutama pada fasilitas umum dan rumah warga. Hal ini diakibatkan karena kedalaman pusat gempa cukup dangkal, sehingga energi rambatan kelombang menuju kepermukaan tanah tidak mengalami pengurangan yang cukup besar. Selain itu, kuallitas bangunan juga menjadi faktor penyebab, sehingga bangunan yang banyak mengalami kerusakan adalah bangun non-engineering.

Berdasarkan fakta kerusakan yang terjadi di lapangan, maka penelitian ini melakukan kajian kerusakan bangunan untuk mengatahui faktor penyebab banyaknya rumah warga dan fasilitas umum mengalami kerusakan yang cukup parah. Beberapa rumah ditemukan roboh dan rata dengan tanah setelah diguncang gempa berkekuatan 4,4 SR ini.

Tujuan dilakukannya penelitian ini adalah untuk meneliti jenis kerusakan bangunan, sehingga dapat diprediksi faktor penyebab terjadinya kerusakan bangunan akibat gempa Banjarnegara di Kecamatan Kalibening.

\section{METODOLOGI}

Analisis kondisi kerusakan bangunan di lapangan pasca gempa dilakukan pada tanggal 21 April 2018 bersama dengan tim Manajemen Rekayasa Kegempaan 
Universitas Islam Indonesia tepatnya di 4 desa yang berada di kecamatan Kalibening yaitu Desa Plorengan, Desa Kasinoman, Desa Kertosari dan Desa Sidakangen.

Proses pengumpulan atau pengambilan data dilakukan dengan melihat langsung ke lokasi terdampak untuk mengetahui kondisi kerusakan bangunan yang terjadi. Data kerusakan bangunan yang diperoleh kemudian diklasifikasikan berdasarkan tingkat kerusakan dan dianalisis untuk memprediksi penyebab kerusakannya.

\section{HASIL DAN PEMBAHASAN}

\section{Analisis Seismologi}

Kejadian gempa terjadi pada Rabu, 18 April 2018 sekitar jam 13.28 WIB pada Koordinat $7^{\circ}, 21$ LS dan $109,65^{\circ}$ BT (Gambar 2) dengan kekuatan 4,4 SR pada kedalaman $4 \mathrm{Km}$. berdasarkan model peta tingkat guncangan (Shakemap) BMKG (Gambar 3) diketahui bahwa tingkat guncangan terbesar terjadi di Kecamatan Kalibening pada Skala II SIG-BMKG (IV-V MMI) (Gambar 4). Berdasarkan laporan masyarakat, guncangan gempa bumi disarakan cukup kuat.

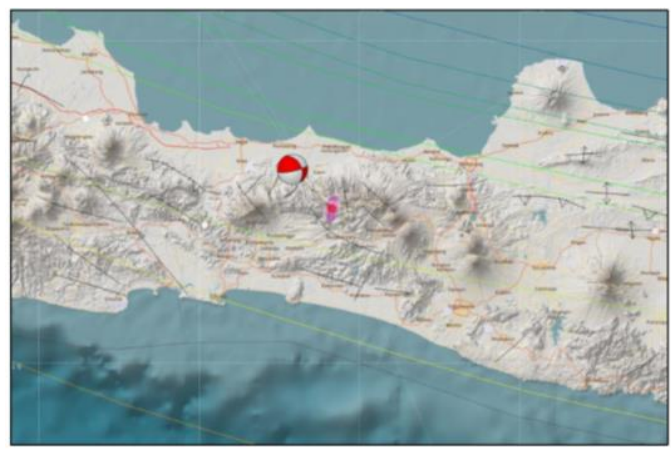

Gambar 2. Lokasi episenter gempa Sumber: BMKG (2018)

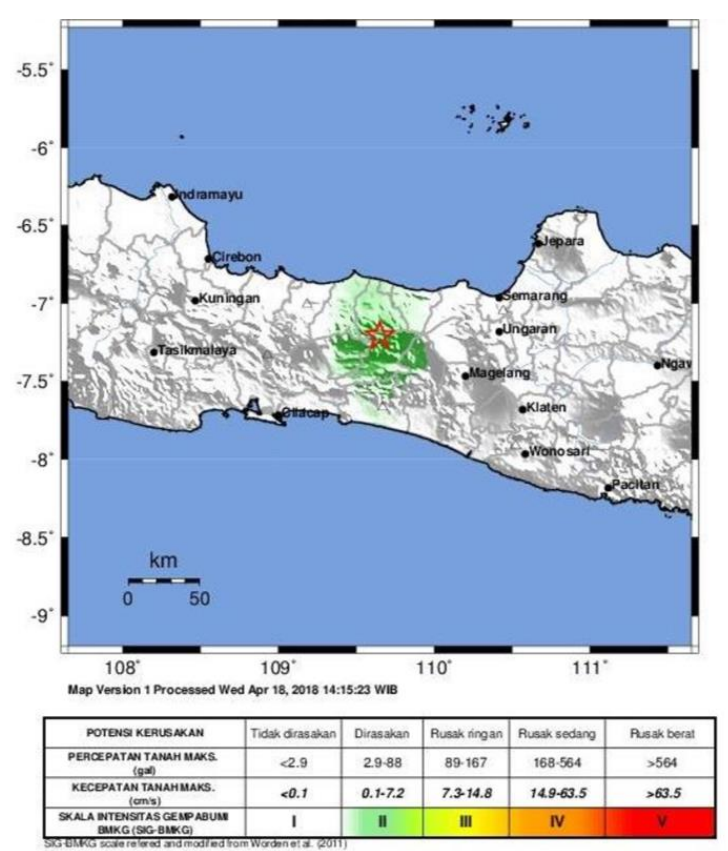

Gambar 3. Shakemap Skala SIG-BMKG Sumber: BMKG (2018)

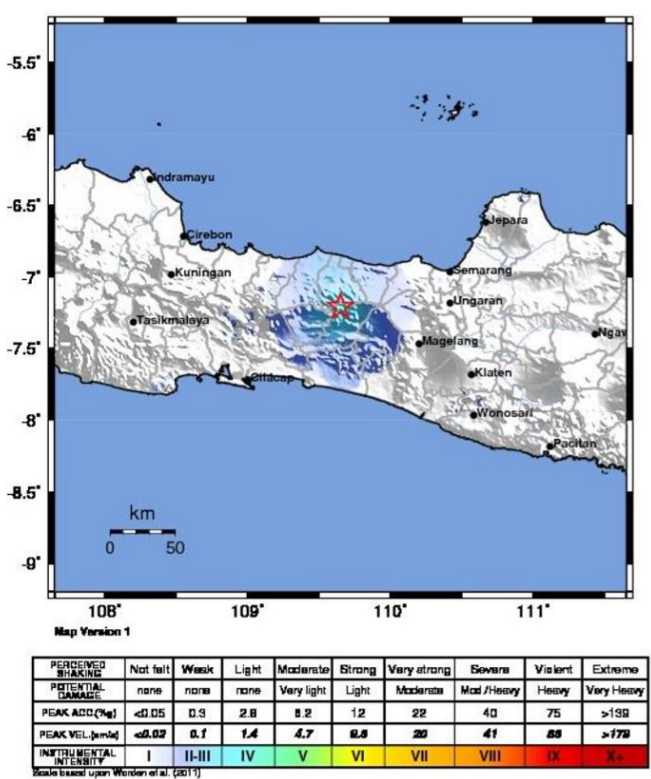

Gambar 4. Shakemap Skala MMI Sumber: BMKG (2018)

\section{Analisis Kerusakan Bangunan}

Berdasarkan hasil investigasi di lapangan, gempa telah meyebabkan banyaknya bangunan mengalami kerusakan. Bangunan yang rusak rata-rata tidak sesuai dengan kaidah bangunan tahan gempa. Berdasarkan tingkat kerusakan di setiap desa, beberapa desa yang mengalami rusak berat adalah Desa Kertosari dan Desa Kasinoman. Rekapitulasi kerusakan bangunan di Kecamatan Kalibening ditunjukkan dalam tabel 1 dan 2.

Tabel 1. Rekapitulasi Data Kerusakan Infrastruktur Bangunan Rumah

\begin{tabular}{lcccc}
\hline \multirow{2}{*}{ Desa } & \multicolumn{3}{c}{ Tingkat Kerusakan } & \multirow{2}{*}{ Jml } \\
\cline { 2 - 4 } & Ringan & Sedang & Berat & \\
\hline Plorengan & 40 & 7 & 5 & 52 \\
Kasinoman & 48 & 16 & 30 & 94 \\
Kertosari & 0 & 0 & 44 & 44 \\
Sidakangen & 0 & 8 & 3 & 11 \\
\hline \multicolumn{1}{c}{ Total } & $\mathbf{8 8}$ & $\mathbf{3 1}$ & $\mathbf{8 2}$ & $\mathbf{2 0 1}$ \\
\hline
\end{tabular}

Sumber: BPBD Kab. Banjarnegara (2018)

Tabel 2. Rekapitulasi Data Kerusakan Fasilitas Umum

\begin{tabular}{|c|c|c|c|c|}
\hline \multirow{2}{*}{ Desa } & \multirow{2}{*}{ Jenis } & \multicolumn{2}{|c|}{ Tingkat Kerusakan } & \multirow{2}{*}{ Jml } \\
\hline & & $\begin{array}{ll}\mathbf{R} & \mathbf{S} \\
\end{array}$ & B & \\
\hline Plorengan & Masjid & & 1 & 1 \\
\hline \multirow[t]{3}{*}{ Kasinoman } & Masjid & 1 & & 1 \\
\hline & Musholla & 1 & & 1 \\
\hline & SDN & 1 & & 1 \\
\hline $\begin{array}{l}\text { Kertosari } \\
\text { Sidakangen }\end{array}$ & Masjid & 1 & & 1 \\
\hline Total & & 4 & 1 & 5 \\
\hline
\end{tabular}

Sumber: BPBD Kab. Banjarnegara (2018)

Beberapa penyebab kegagalan struktur bangunan akibat gempa yang dirangkum dari hasil pengamatan di lapangan dijelaskan sebagai berikut.

1. Kegagalam Sambungan

Pada Gambar 5 terlihat contoh kasus kegagalan beam coloumn joint, sehingga mengakibatkan sistem sambungan antara balok dan kolom sangat rentan terhadap beban siklis akibat gempa. Beban ini menimbulkan tegangan geser yang cukup besar pada daerah sambungan 
dan sangat berpotensi terjadi kegagalan geser. Setelah beam coloumn joint mengalami kegagalan maka dinding akan ikut runtuh secara otomatis, dikarenakan dinding tidak didisain untuk menahan beban gempa.

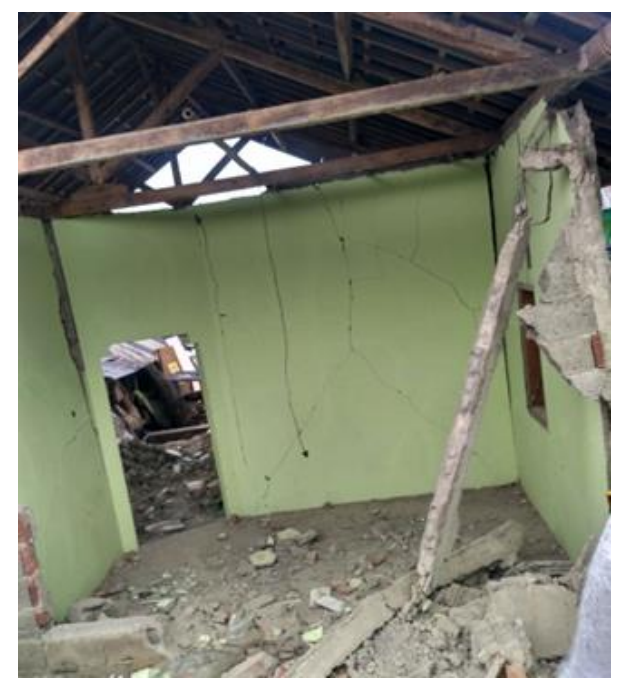

Gambar 5. Kegagalan Sambungan

Sumber: Kunjungan Lapangan (2018)

Secara umum kegagalan sambungan disebabkan oleh beberapa faktor, seperti jarak antar tulangan geser yang terlalu jauh dan kekuatan sambungan yang tidak cukup akibat pendetailan tulangan yang kurang baik (Teguh, 2018).

\section{Kegagalan Sendi Plastis}

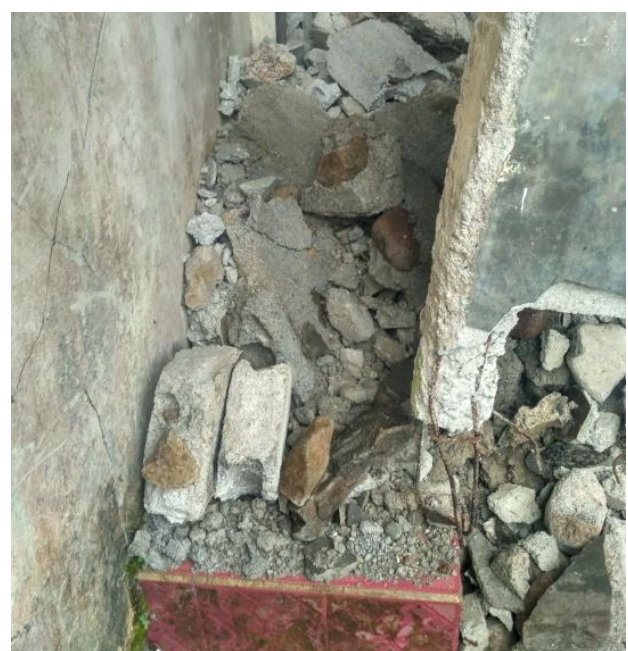

Gambar 6. Kegagalan Sendi Plastis pada Kolom

Sumber: Kunjungan Lapangan (2018)

Kegagalan sendi plastis pada kolom seperti terlihat pada gambar 6, kemungkinan diakibatkan karena kualitas beton yang kurang baik dan diameter serta jarak antar tulangan geser yang tidak mengikuti persyaratan bangunan tahan gempa. Terlihat pada gambar 6 jarak antar tulangan geser cukup jauh. Pada saat terjadi gempa, kolom akan mengalami tegangan yang cukup besar pada area sambungan, sehingga kolom tidak kuat menahan beban siklis dan menyebabkan kerusakan pada sendi plastis.
Kerusakan terlihat pada area sambungan kolom dan sloff atau pondasi.

\section{Kegagalan Ikatan Kolom ke Pondasi}

Kegagalan ikatan antara kolom dan pondasi pada bangunan non engineering ketika terjadi gempa sering ditemukan pada beberapa daerah terdampak gempa, kebanyakan bangunan non engineering tidak dibangun oleh tenaga ahli dan tidak memperhatikan risiko kerusakan apabila terjadi gempa. Dari hasil pengamatan diketahui bahwa kegagalan ikatan antara kolom dan fondasi pada bangunan di Banjarnegara disebebkan karena tidak adanya angkur atau pengait antar kolom ke pondasi, sedangkan tegangan geser pada area sambungan kolom dengan pondasi cukup besar. Hal itu mengakibatkan kolom tidak kuat menahan tengangan geser dan akan tercabut atau terlepas dari ikatan pondasi sehingga menyebabkan keruntuhan.

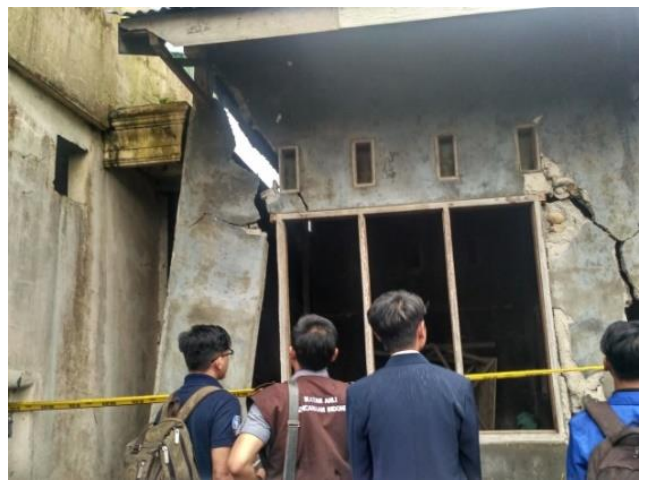

Gambar 7. Kegagalan Ikatan Kolom ke pondasi (sloof) Sumber: Kunjungan Lapangan (2018)

4. Memanfaatkan Bambu sebagai Pengganti Baja pada Tulangan Pokok

Pada penelitian sebelumnya sudah banyak ditemukan penelitian yang membahas penggunaan bambu sebagai alternatif pengganti tulangan baja tarik. Bambu dikenal memiliki sifat kuat tarik sejajar serat yang cukup tinggi, ulet, lurus, rata, keras, mudah dibelah, mudah dibentuk dan mudah dikerjakan serta ringan (Kasiati, 2010).

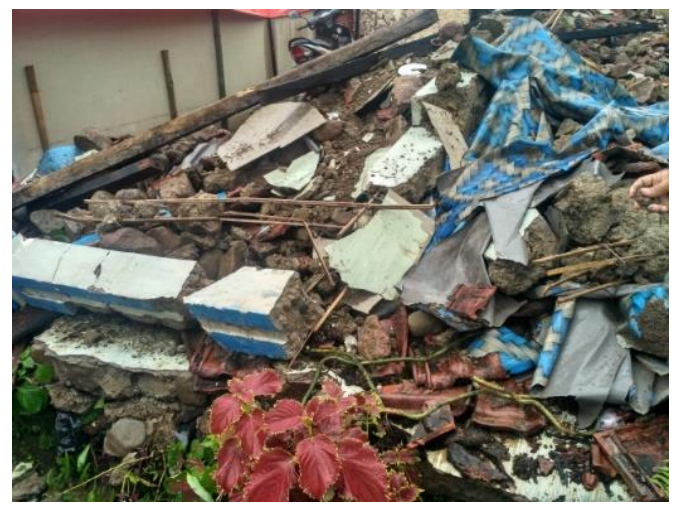

Gambar 8. Pengunaan Bambu sebagai Tulangan Pokok Sumber: Kunjungan Lapangan (2018) 
Pemanfaatan bambu sebagai pengganti tulangan baja tarik harus melalui beberapa perlakuan terhadap bambu, sebelum digunakan. Salah satu perlakuan adalah berkaitan dengan tingkat keawetannya. Menurut Wonlele et al (2013) kekuatan bambu akan menurun dalam waktu kurang dari satu tahun, sehingga perlu dilakukan pengawetan agar bambu bisa tahan dalam waktu yang cukup lama.

Gambar 8 memperlihatkan contoh kegagalan akibat penerapan tulangan bambu sebagai pengganti tulangan tarik baja. berdasarkan analisis di lapangan, kondisi bambu yang ditemukan sangat mudah rapuh dan kurang menyatu dengan beton. Berdasarkan fakta tersebut dapat ditarik kesimpulan bahwa pada saat proses pembangunan, penggunaan bambu sebagai pengganti tulangan baja tarik tidak melewati proses pengawetan terlebih dahulu dan tidak dilakukan pemilihan mutu bambu dengan baik.

\section{Campuran Beton yang Kurang Baik}

Komposisi beton terdiri dari agregat kasar, agregat halus, semen dan air. Dalam Peraturan Beton Bertulang Indonesia (PBI 1971) disyaratkan bahwa agregat halus tidak mengandung lumpur lebih dari 5\%, dedangkan untuk agregat kasar tidak mengandung lumpur lebih dari $1 \%$. Namun dilapangan seringkali persyaratan tersebut diabaikan.

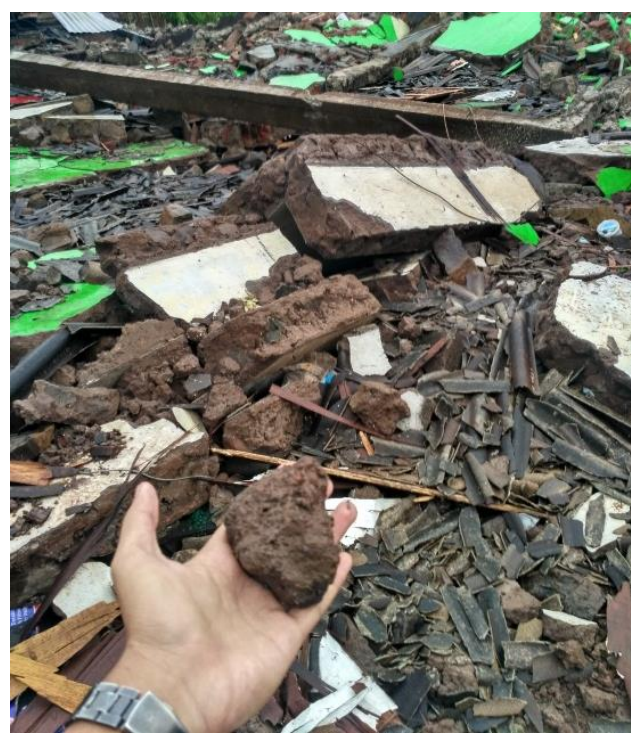

Gambar 9. Kualitas Pasir pada Campuran Beton Kurang Baik

Sumber: Kunjungan Lapangan (2018)

Gambar 9 menunjukkan campuran beton yang diperoleh dari reruntuhan bangunan, terlihat bahwa kandungan lumpur dalam agregat halus lebih dari 5\%. Akibat dari banyaknya kandungan lumpur dalam campuran beton tersebut menyebabkan kuat tekan beton menjadi berkurang. Hal ini terbukti pada kasus di Banjarnegaran, terdapat rumah yang hancur dan rata dengan tanah (Gambar 9). Terlihat bahwa beton berwarna agak kecoklatan, yang mengindikasikan bahwa terdapat kandungan lumpur yang cukup banyak di dalamnya.

\section{Kerusakan Dinding}

Kerusakan dinding pasca gempa sangat sering ditemukan pada gempa berkekuatan besar maupun kecil. Pada umumnya kerusakan dinding terjadi di daerah pertemuan antara kolom dengan dinding dan di sekitar frame jendela dan pintu. Kerusakan yang ditunjukkan pada Gambar 10 merupakan contoh kerusakan dinding yang terjadi pada frame jendela, dimana kerusakan dinding terjadi pada daerah sudut frame.

Secara umum, daerah yang terbuka merupakan daerah lemah (weakness zone), karena tidak memiliki penahan yang memadai atau tidak memiliki kekakuan yang cukup. Hal tersebut mengakibatkan konstraksi tegangan akibat gempa terkonsentrasi pada daerah lemah dan menyebabkan keretakan atau keruntuhan seperti yang terjadi pada bangunan yang ditunjukkan dalam Gambar 8 .

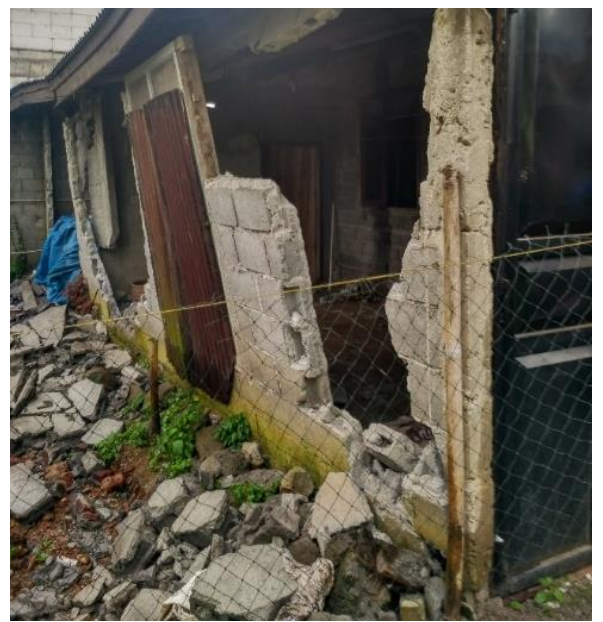

Gambar 10. Keruntuhan Dinding pada Frame Jendela Sumber: Kunjungan Lapangan (2018)

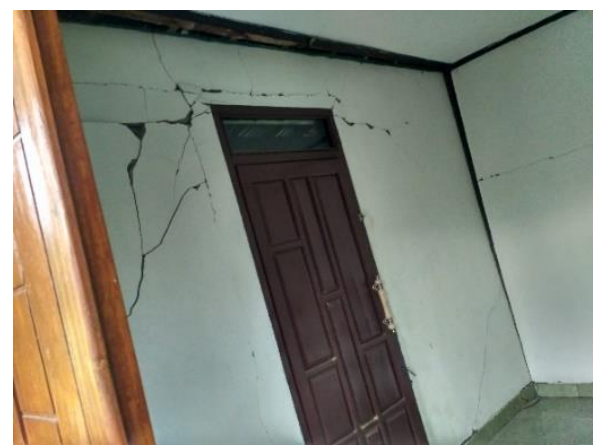

Gambar 11. Keretakan Dinding pada Frame Pintu Sumber: Kunjungan Lapangan (2018)

\section{Mitigasi Struktural}

Dari hasil pengamatan di lapangan, diketahui bahwa bangunan yang mengalami kerusakan pada saat terjadi gempa besar di Indonesia didominasi oleh bangunan sederhana. Hal ini disebabkan karena pembangunan rumah sederhana seringkali tidak dikerjakan oleh tenaga ahli dan tidak dibangun berdasarkan konsep bangunan tahan gempa. Akibatnya bangunan menjadi sangat membahayakan keselamatan penghuninya, terutama pada bangunan yang berada di lokasi rawan gempa. Oleh 
karena itu, perlu dilakukan evaluasi kerusakan yang terjadi dan diberikan solusi mitigasi structural yang semestinya.

\section{Antisipasi Kegagalan Sambungan}

Secara umum balok pada bangunan sederhana terdiri dari ring balk dan sloof, atau seringkali ditambahkan balok lintel yang berfungsi sebagai penguat arah horizontal. Pada saat terjadi gempa, tegangan geser terbesar terjadi pada area sambungan antara balok dengan kolom atau dengan dinding. Oleh karena itu, perlu dilakukan pendetailan tulangan yang lebih kompleks seperti ditunjukkan pada Gambar 12.

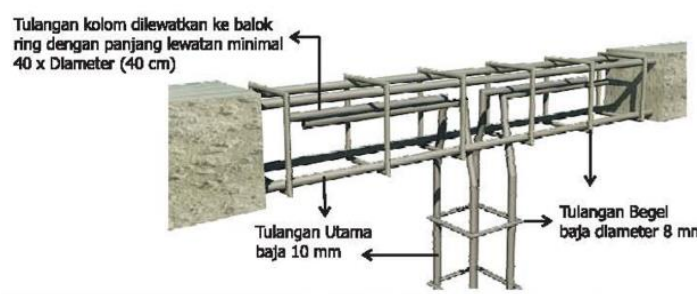

Gambar 12. Detail Tulangan Balok ring

Sumber: Buku Saku Persyaratan Pokok Rumah yang Lebih Aman, 2009.

Pada Gambar 12 terlihat bahwa pada pertemuan kolom dan balok ring, tulangan kolom dilewatkan atau diangkur ke dalam balok ring dengan panjang minimum 40 kali diameter (40D). Diameter tulangan utama pada kolom dan balok ring direkomendasikan sebesar $\varnothing 10 \mathrm{~mm}$, sedangkan untuk tulangan begel sebesar $\varnothing 8 \mathrm{~mm}$.

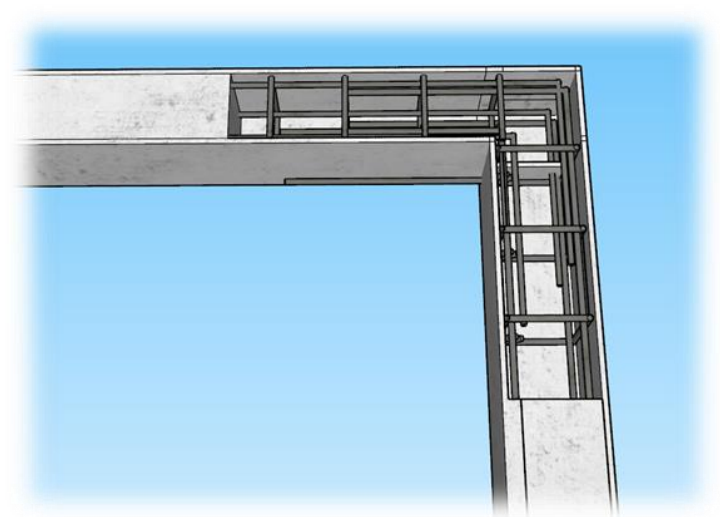

Gambar 13. Detail tulangan balok ring - kolom (Tengah)

Pendetailan tulangan sambungan antara balok ring dan kolom pada daerah sudut ditunjukkan pada Gambar 13. Penyaluran tulangan, pada daerah sudut ini dilakukan pada tulangan kolom maupun balok, berbeda dengan penyaluran pada sambungan di tengah balok (Gambar 12) yang dilakukan hanya pada tulangan kolom saja, namun panjangnya sama yaitu 40D.

\section{Antisipasi Kegagalan Sendi Plastis pada Kolom}

Pada saat terjadi gempa, sambungan tulangan pada pertemuan antara kolom dan balok sloof akan mengalami tegangan geser yang cukup besar karena kolom merupakan struktur utama yang mendistribusikan beban bangunan ke pondasi. Untuk mengantisipasi kegagalan geser maka jarak tulangan begel perlu diperhatikan. Tulangan begel berfungsi sebagai penahan gaya geser, sehingga semakin dekat jarak antar tulangan begel maka kemampuan untuk menahan gaya geser akan semakin besar pula. Jarak antar tulangan begel pada kolom yang diisyaratkan terlihat pada Gambar 14.

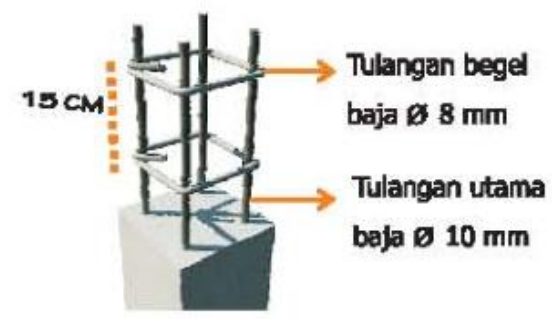

Gambar 14. Jarak Tulangan Begel Kolom

Sumber : Buku Saku Persyaratan Pokok Rumah yang Lebih Aman, 2009.

Gambar 14 menunjukkan bahwa dimensi kolom untuk bangunan sederhana minimum 15 x $15 \mathrm{~cm}$ dengan diameter tulangan pokok $10 \mathrm{~mm}$ dan tulangan begal $8 \mathrm{~mm}$. Jarak antar begel minimum $15 \mathrm{~cm}$ dan tebal selimut beton $15 \mathrm{~mm}$.

\section{Antisipasi Lepasnya Kolom dari Ikatan Pondasi}

Kolom pada bangunan sederhana berfungsi membantu dinding dalam menahan beban yang berada di atasnya. Pada bangunan dengan pengisi dinding, kolom juga berfungsi dalam menjadikan dinding menjadi lebih daktail. Oleh karena itu kolom tidak boleh lepas dari ikatan dengan pondasi atau balok sloof. Apabila kolom lepas dari ikatannya dengan balok sloof maka kolom tidak akan bisa lagi tegak secara stabil. Selain lepasnya kolom dari ikatan dengan balok sloof mengakibatkan dinding tidak kuat menahan beban yang berada di atasnya. Dengan demikian ikatan kolom ke balok sloff sangat penting untuk diperhatikan. Gambar 15 dan 16 menunjukkan ikatan kolom ke balok sloof dan ikatan balok sloof ke pondasi yang sudah didesain dengan mempertimbangkan bahaya gocangan gempa.

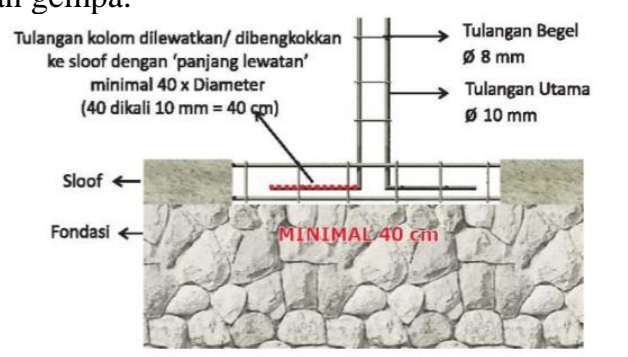

Gambar 15. Ikatan kolom - Balok Sloof 


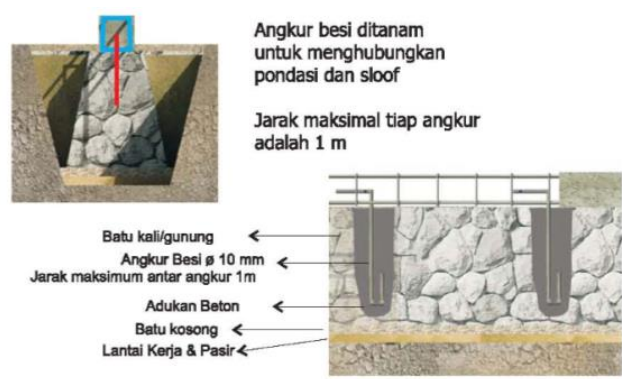

Gambar 16. Ikatan Balok Sloof - Pondasi

Sumber : Buku Saku Persyaratan Pokok Rumah yang Lebih Aman, 2009.

4. Antisipasi Kualitas Campuran Beton yang Kurang Baik

Baik buruknya kualitas campuran beton akan sangat berpengaruh terhadap kinerja suatu bangunan, Buruknya kualitas suatu campuran biasanya disebabkan karena komposisi agregat halus yang kurang baik seperti memliki kandungan lumpur cukup banyak sehingga mengurangi daya rekat dari campuran tersebut. Berdasarkan pada PBI 1971, dijelaskan bahwa batas maksimum kadungan lumpur yang terkandung dalam agregat halus adalah sebesar $5 \%$.

Ciri-ciri agregat halus yang baik dapat diprediksi dari beberapa eksperimen. Pada saat pasir dilemparkan ke suatu bahan pakaian, maka pasir tidak akan merekat. Selain itu, apabila pasir digenggam tidak terjadi pungumpulan dan pasir terasa tajam bila diremas. Selain dari kualitas agregat halus, komposisi campuran pada beton yang terdiri dari Pasir, Kerikil dan Semen juga sangat penting untuk diperhitungkan. Berikut ini merupakan gambar Komposisi campuran beton dan mortar yang telah diisyaratkan berdasarkan bahaya ancaman gempa (Gambar 17-18).

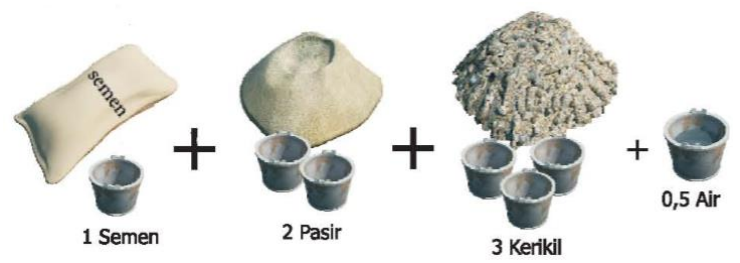

Gambar 17. Campuran Beton

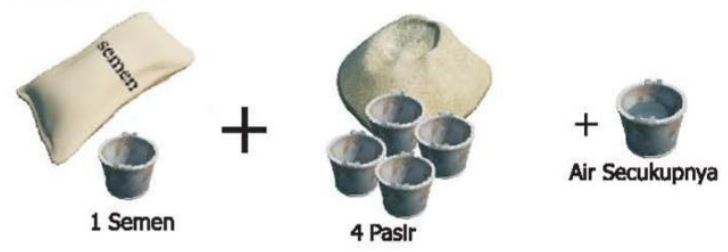

Gambar 18. Campuran Mortar

Sumber : Buku Saku Persyaratan Pokok Rumah yang Lebih Aman, 2009.

\section{Antisipasi Terjadi Kerusakan pada Dinding}

Dinding bangunan pada saat terjadi gempa akan menerima beban permukaan pada arah tegak lurus dinding dan beban geser pada arah sejejar dinding seperti diilustrasikan pada Gambar 19.

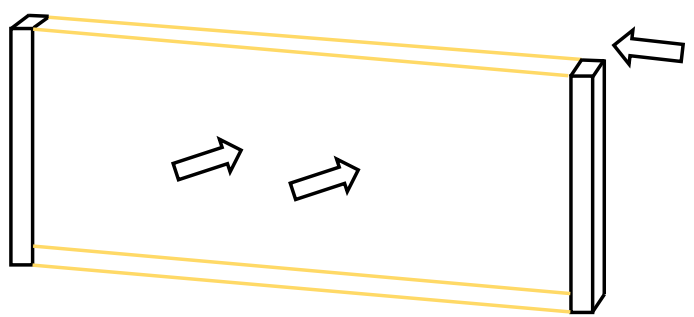

Gambar 19. Beban yang diterima dinding pada saat terjadi gempa

Pada saat menerima beban arah tegak lurus, dinding tidak memiliki kemampuan yang cukup kuat untuk menahan beban, sehingga dinding mudah untuk retak dan roboh. Untuk menambah kekuatan dinding dalam menahan beban gempa, maka dipasang angkur yang mengikat

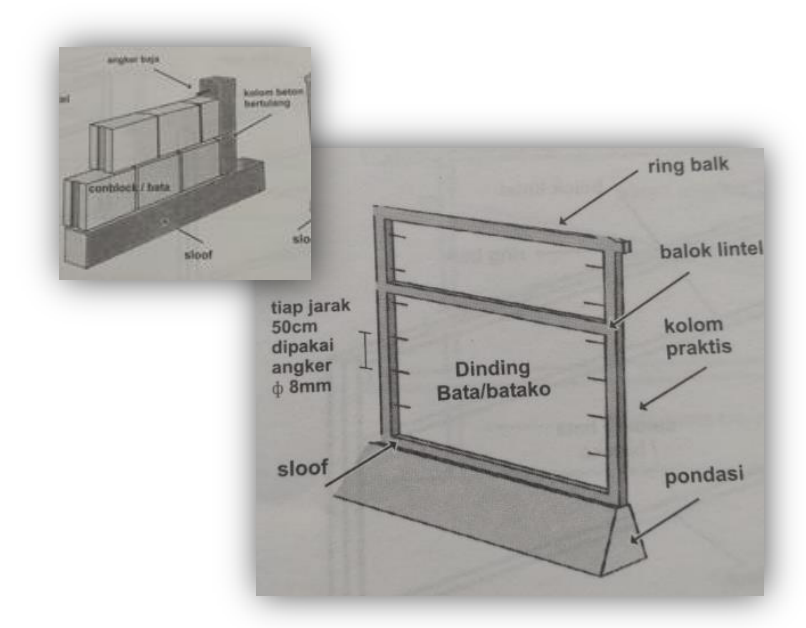

dinding dengan kolom. Digunakan panjang angkur sepanjang 1,5 kali panjang batu bata, yang dipasang pada setiap 10 lapis bata merah atau tiap 3 lapis batako. Untuk lebih memahami, diberikan sketsa pada Gambar 20 di bawah ini.

Gambar 20. Perkuatan pada dinding

Sumber : Barraataga, 2006.

Selain memberikan angkur, luas dinding antar kolom juga perlu diperhatikan, Pada dinding harus diberikan kolom praktis dan balok pengikat terutama pada bagian dinding yang mempunyai luas lebih dari $12 \mathrm{~m} 2$ atau panjang dinding 20 kali tebal dinding (Sarwidi, 2006).

\section{Teknik Penggunaan Bambu sebagai Pengganti Tulangan}

Pemanfaatan bambu sebagai tulangan memiliki beberapa keunggulan dan kelemahan apabila dibandingkan dengan baja. Dalam waktu tidak sampai setahun kekuatan bambu bisa berkurang. Oleh karena itu, untuk menjaga penurunan kekuatan bambu perlu dilakukan pengawetan. Selain untuk meningkatkan kekuatan, tujuan dari pengawetan adalah memperpanjang usia komponen bambu.

Permasalahan yang terjadi pada kegagalan penggunaan bambu seperti ditunjukkan pada Gambar 8 
adalah kondisi bambu yang sangat lemah dan rapuh. Hal itu terbukti pada kondisi bambu yang ditemukan di lapangan, ketika dipegang mudah hancur, diduga tidak dilakukan pengawetan terlebih dahulu pada bambu yang akan digunakan, serta tidak dilakukan pemilihan bambu yang memiliki kekuatan memadai.

Selain dari faktor pengawetan, disimpulkan oleh beberapa peneliti terdahulu (Wonlele, 2013) bahwa kegagalan terkadang disebabkan oleh tulangan bambu mengalami slip dengan beton. Bambu dan beton tidak bisa merekat dengan baik, kerena ketika pengecoran, air diserap oleh bambu dan mengakibatkan bambu menjadi mekar. Sementara itu pengerjaan akan lebih sulit ketika bambu dalam kondisi kering. Salah cara untuk mengatasi permasalah tersebut adalah dengan memanfaatkan cat dan pasir. Cat dan lebur pasir dimanfaatkan untuk menutup pori-pori bambu sehingga menjadi kasar dan lengket dengan beton.

\section{Kesiapsiagaan Terhadap Reruntuhan Bangunan}

Upaya mitigasi bencana gempabumi tidak hanya dilakukan dari segi struktural tetapi juga non struktural, kesiapsiagaan masyarakat dalam menghadapai bencana gempabumi menjadi salah satu faktor penting dalam mitigasi. Pada saat kejadian gempa biasanya terjadi kepanikan dimasyarakat sehingga potensi untuk tertimpa reruntuhan bangunan akan besar. Beberapa upaya peningkatan kesiapsiagaan dalam menghadapi ancaman gempabumi seperti memperhatikan penataan ruang yang memudahkan proses evakuasi, penentuan jalur evakuasi dan titik kumpul, membuat rambu dan papan informasi, serta memperhatikan arah bukaan pintu yang mempercepat proses evakuasi (Faizah et al, 2017).

\section{KESIMPULAN DAN SARAN \\ Kesimpulan}

Berdasarkan hasil investigasi di lapangan maka dapat disimpulkan sebagai berikut:

1. Salah satu penyebab kerusakan bangunan paska gempa Banjarnegara adalah aspek kedalaman gempa yang dangkal, yaitu $4 \mathrm{~km}$.

2. Bangunan rumah, sekolah dan masjid yang rusak atau roboh disebabkan karena tidak mengikuti kaidahkaidah bangunan tahan gempa, seperti sistem struktur yang kurang menyatu dan kualitas material yang kurang baik.

3. Kerusakan beberapa bangunan paska gempa Banjarnegara juga disebabkan adanya penggunaan bambu sebagai pengganti tulangan yang tidak mengikuti tata cara yang benar.

\section{Saran}

Disarankan untuk dibangun kesiapsiagaan daerah Banjarnegara yang memiliki banyak potensi bencana, baik berupa kesiapsiagaan bangunan maupun masyarakatnya. Sosialisasi bangunan tahan gempa dan simulasi kesiapan masyarakat dalam merespon bencana juga sangat disarankan.

\section{DAFTAR PUSTAKA}

Antonious, 2007, Kajian Faktor-Faktor yang Mempengaruhi Tingkat Kerusakan Bangunan Akibat Gempa Bumi (Studi Kasus Gempa di NTB 2004). Seminar Nasional Teknik Sipil III-2007, Tema : Peran Teknik Sipil dalam Manajeman Bencana. Pp G1-G7.

$\begin{array}{cclc}\text { BMKG, 2018, Press } & \text { Release } & \text { NO } \\ \text { UM.505/10/D3/IV/2018, } & \text { Badan } & \text { Meteorologi } \\ \text { Klimatologi Dan Geofisika. } & & \end{array}$

Boen T et al , 2009, Buku Saku Persyaratan Pokok Rumah yang Lebih Aman, The Project on Building Administartion and Enforcement Capacity Develovment for Seismic Resilience.

Departemen Pekerjaan Umum, 1971, Peraturan Beton Bertulang Indonesia, Bandung : Badan Penelitian dan Pengembangan Departemen Pekerjaan Umum.

Faizah et al, 2017, Studi Identifikasi Mitigasi Bencana Gempa pada Bangunan Sekolah Dasar Kaligondang dan Rekomendasi Perbaikan, Rekayasa Sipil Vol. 6 No. 2 September 2017, Pp 98-112.

Ismail, 2011, Identifikasi Kegagalan Struktur dan Alternatif Perbaikan Serta Perkuatan Gedung BPKP Provinsi Sumatera Barat, Jurnal Rekayasa Sipil Vo. 7 No. 2, Pp 1-14.

Kasiati, 2010, Pilinan Bambu sebagai Alternatif Pengganti Tulangan Tarik pada Balok Beton, Jurnal Aplikasi Vol. 8 No. 1, Februari 2010. Pp 9-17.

Mukhlis, 2013, Pengaruh Beberapa Jenis Pasir Terhadap Kekuatan Beton, Poli Rekayasa Vol. 9, No. 1, Oktober 2013. Pp 49-55.

Nuswantoro, 2010, Analisis Jenis Kerusakan pada Bangunan Perumahan (Studi Kasus pada Perumahan Pondok Pasir Mas Palangka Raya), Jurnal Rekayasa Rancang Bangun, Vol. 11, No. 1, Juni 2010. Pp 1-14.

Sarwidi. 2006. Mannual BARRATAGA Dinding Tembokan. Kerjasama CEEDEDS UII dengan Pemerintah Jepang.

Satgas Unsyiah, 2016, Laporan Kaji Cepat Uiversitas Syiah Kuala Terhadap Gempabumi 6,5 Mw Tanggal 7 Desember 2016 di Sekitar Pidie Jaya - Aceh. Satuan Tugas Pemulihan Gempa Pidie Jaya Universutas Syiah Kuala.

Teguh, 2013, Assesmen Struktur Bangunan Gedung Bertingkat di Kota Padang Pasca Gempa 2006, Proceeding Seminar Nasional dan Pameran ke IV HASTAG. Pp 149-168. 
Wonlele et al, 2013, Penerapan Bambu Sebagai Tulangan Dalam Struktur Rangka Batang Beton Bertulang, Jurnal Rekayasa Sipil / Vol. 7 No. 1, Pp 1-12.

Zaidir et.al, 2018, Perbaikan dan Perkuatan Bangunan Pasca Gempa Sumatera Barat Tahun 2009. Prosiding PIT Ke-5 Riset Kebencanaan IABI Universitas Andalas, Padang 2-4 Mei 2018. Pp 731-742. 